\title{
Preface: "Improving seismic networks performances: from site selection to data integration (EGU2019 SM5.2 session)"
}

\author{
Damiano Pesaresi ${ }^{1}$, Helle Pedersen ${ }^{2}$, and Angelo Strollo ${ }^{3}$ \\ ${ }^{1}$ Centro di Ricerche Sismologiche, Istituto Nazionale di Oceanografia e di Geofisica Sperimentale - OGS, Udine, 33100, Italy \\ ${ }^{2}$ Univ. Grenoble Alpes, Univ. Savoie Mont Blanc, CNRS, IRD, IFSTTAR, ISTerre, Grenoble, 38000, France \\ ${ }^{3}$ Helmholtz Centre Potsdam - GFZ German Research Centre for Geosciences, Potsdam, 14473, Germany
}

Correspondence: Damiano Pesaresi (dpesaresi@inogs.it)

Received: 10 January 2020 - Published: 28 January 2020

\begin{abstract}
The number and quality of seismic stations and networks in Europe continually improves, nevertheless there is always scope to optimize their performance. In this EGU2019 SM5.2/GI4.13 session we welcomed contributions from all aspects of seismic network installation, operation and management. This includes site selection; equipment testing and installation; planning and implementing communication paths; policies for redundancy in data acquisition, processing and archiving; and integration of different data sets including GPS and OBS.
\end{abstract}

\section{Introduction}

The history of seismic networks sessions at European Geosciences Union (EGU) general assemblies started in 2010 with the SM1.3 "Seismic Centres Data Acquisition" session (Pesaresi, 2011), where the convener Damiano Pesaresi supported by the Orfeus Data Centre (ODC) Director coconvener Reinoud Sleeman chaired a session of 7 oral and 16 poster presentations. Later in the same year a similar session was held at the XXXII European Seismological Commission (ESC) General Assembly: "SD1, 3 Seismic centres data acquisition", conveners Damiano Pesaresi and Reinoud Sleeman, with 15 oral presentations.

The history of these sessions continued in 2011 with the EGU2011 SM1.3/G3.8/GD3.7/GI-19/TS8.7 "Improving seismic networks performances: from site selection to data integration" session (EGU2011, 2011), where the convener Damiano Pesaresi supported by the co-conveners John Clinton and Robert Busby chaired a session of 9 oral and 20 poster presentations; in 2012 with the EGU2012
SM1.3/GI1.7 "Improving seismic networks performances: from site selection to data integration" session (Pesaresi and Vernon, 2013), where the convener Damiano Pesaresi supported by the co-convener Frank Vernon chaired a session of 6 oral and 22 poster presentations; in 2013 with the SM1.4/GI1.6 "Improving seismic networks performances: from site selection to data integration" session (Pesaresi and Busby, 2013), where the convener Damiano Pesaresi supported by the co-convener Robert Busby chaired a session of 6 oral and 13 poster presentations; in 2014 with the EGU2014 SM1.2/GI3.7 "Improving seismic networks performances: from site selection to data integration" session (Pesaresi et al., 2015), where the convener Damiano Pesaresi supported by the co-conveners John Clinton and Helle Pedersen chaired a session of 12 oral and 27 poster presentations; in 2015 with the EGU2015 SM1.2/GI1.5 "Improving seismic networks performances: from site selection to data integration" session (EGU2015, 2015), where the convener Damiano Pesaresi supported by the co-conveners Helle Pedersen and Yuri Starovoit chaired a session of 20 poster presentations; in 2016 with the EGU2016 SM7.3 "Improving seismic networks performances: from site selection to data integration" session (EGU2016, 2016), where the convener Damiano Pesaresi supported by the co-conveners Helle Pedersen and John Clinton chaired a session of 6 oral and 16 poster presentations; in 2017 with the EGU2017 SM5.3 "Improving seismic networks performances: from site selection to data integration" session (EGU2017, 2017), where the convener Damiano Pesaresi supported by the co-conveners Helle Pedersen and Christos Evangelidis chaired a session of 15 poster presentations; and in 2018 with the EGU2018 SM5.01/NH4.16 "Ground translation, strain and rotation: 
SM5.2

Improving seismic networks performances: from site selection to data integration '

Co-organized as GI4.13

Convener: Damiano Pesaresi Q | Co-conveners: Helle Pedersen Q, Angelo Strollo Q

- Orals | Wed, 10 Apr, 08:30-10:15 $\square$ Room -2.91

- Posters | Attendance Wed, 10 Apr, 16:15-18:00 $\square$ Hall X2

The number and quality of seismic stations and networks in Europe continually improves, nevertheless there is always scope to optimize their performance. In this session we welcome contributions from all aspects of seismic network installation, operation and management. This includes site selection; equipment testing and installation; planning and implementing communication paths; policies for redundancy in data acquisition, processing and archiving; and integration of different datasets including GPS and OBS.

Figure 1. The EGU2019 SM5.2/GI4.13 “Seismic Networks" session.

Table 1. Oral programme for the EGU2019 SM5.2/GI4.13 session.

\begin{tabular}{|c|c|c|}
\hline EGU Abstract ref. & Title & Authors \\
\hline EGU2019-1807 & The new progress of China Array project & Songyong Yuan and Weiwei Xu \\
\hline EGU2019-3034 & $\begin{array}{l}\text { An Investigation of KOERI Seismic Network and } \\
\text { Earthquake Catalog }\end{array}$ & $\begin{array}{l}\text { Didem Cambaz, Fatih Turhan, Mehmet Yılmazer, K1- } \\
\text { vanç Kekovalı, Öcal Necmioğlu, and Doğan Kalafat }\end{array}$ \\
\hline EGU2019-3205 & $\begin{array}{l}\text { The Namche Barwa Temporary Seismic Network } \\
\text { (NBTSN) and its performance in monitoring the } \\
18 \text { November } 2017 \text { M } 6.9 \text { Mainling, Tibet, China, } \\
\text { earthquake }\end{array}$ & Chaoyong Peng and Jiansi Yang \\
\hline EGU2019-3879 & Telsite: a geophysical instrumentation system & Stephane Denis and Serge Olivier \\
\hline EGU2019-5779 & $\begin{array}{l}\text { Quality control with component ratios: } 20 \text { years of } \\
\text { GEOSCOPE data }\end{array}$ & $\begin{array}{l}\text { Helle Pedersen, Dimitri Zigone, Nicolas Leroy, and } \\
\text { Martin Vallée }\end{array}$ \\
\hline EGU2019-13374 & $\begin{array}{l}\text { ORFEUS Strong-Motion services and products for } \\
\text { engineering seismology }\end{array}$ & $\begin{array}{l}\text { Lucia Luzi, Sleeman Reinoud, Puglia Rodolfo, Koy- } \\
\text { mans Mathijs and the ORFEUS Strong-Motion Service } \\
\text { management Committee }\end{array}$ \\
\hline EGU2019-13810 & New federated seismological services within EIDA & $\begin{array}{l}\text { Javier Quinteros, Daniel Armbruster, Massimo Fares, } \\
\text { Stefan Heimers, Andres Heinloo, Mathias Hoffmann, } \\
\text { Philippe Kaestli, Mathijs Koymans, Erich O. Muhire, } \\
\text { Cristian Neagoe, Mehmet Ozer, Catherine Pequegnat, } \\
\text { Jonathan Schaeffer, Luca Trani, and Nikolaos Tri- } \\
\text { antafyllis }\end{array}$ \\
\hline
\end{tabular}

New and improved instrumentation and applications" session (EGU2018, 2018), where the convener André Gebauer supported by the co-conveners Helle Pedersen, Angelo Strollo, Damiano Pesaresi, Christian Schubert, Stephanie Durand, and Stefanie Donner chaired a session of 12 oral and 27 poster presentations.

\section{The EGU2019 SM5.2/GI4.13 "Seismic Networks" session}

In the EGU2019 SM5.2/GI4.13 "Improving seismic networks performances: from site selection to data integration" session (EGU2019, 2019) the convener Damiano Pesaresi supported by the co-conveners Helle Pedersen and Angelo Strollo chaired a session (Fig. 1) of 7 orals (Table 1) and 17 posters (Table 2 ) presentations.

The 24 presentations came from 15 countries (China, Turkey, France, The Netherlands, Taiwan, Russia, USA, 
Table 2. Poster programme for the EGU2019 SM5.2/GI4.13 session.

\begin{tabular}{|c|c|c|}
\hline EGU Abstract ref. & Title & Authors \\
\hline EGU2019-281 & $\begin{array}{l}\text { Seismic Arrays in the Taipei Metropolis of Northern } \\
\text { Taiwan }\end{array}$ & Win Gee Huang \\
\hline EGU2019-1177 & $\begin{array}{l}\text { Optimal time windows length to study frequency } \\
\text { content of a record after a big earthquake: case } \\
\text { study of KHZ (Geonet network) }\end{array}$ & Aleksei Muryskin and Anna Skorkina \\
\hline EGU2019-1805 & $\begin{array}{l}\text { Comparisons between different installations of } \\
\text { broadband seismometers at soft soil site }\end{array}$ & Weiwei Xu and Songyong Yuan \\
\hline EGU2019-2417 & $\begin{array}{l}\text { Recent Advances to PASSCAL Software for Man- } \\
\text { aging and Archiving Seismic Data }\end{array}$ & $\begin{array}{l}\text { Derick Hess, Lloyd Carothers, Bruce Beaudoin, and } \\
\text { Nick Falco }\end{array}$ \\
\hline EGU2019-2499 & $\begin{array}{l}\text { Performance of a Low-Cost Earthquake Early } \\
\text { Warning System (P-Alert) and shake map produc- } \\
\text { tion during the } 2018 \mathrm{Mw} 6.4 \text { Hualien (Taiwan) } \\
\text { Earthquake }\end{array}$ & Yih-Min Wu \\
\hline EGU2019-5723 & $\begin{array}{l}\text { Preliminary seismological monitoring for geother- } \\
\text { mal development in Vienna, Austria }\end{array}$ & $\begin{array}{l}\text { Maria-Theresia Apoloner, Fee-Alexandra Rodler, } \\
\text { Stefan Weginger, Yan Jia, and Wolfgang Lenhardt }\end{array}$ \\
\hline EGU2019-6702 & $\begin{array}{l}2016 \text { Central Italy Earthquakes Recorded by Low- } \\
\text { Cost MEMS-Distributed Arrays }\end{array}$ & $\begin{array}{l}\text { Jacopo Boaga, Filippo Casarin, Giancarlo De Marchi, } \\
\text { Maria Rosa Valluzzi, Nicola Cenni, and Giorgio Cas- } \\
\text { siani }\end{array}$ \\
\hline EGU2019-7691 & $\begin{array}{l}\text { Quality Improvement of the French Permanent } \\
\text { Broadband Stations with Shallow Posthole } \\
\text { Installations }\end{array}$ & $\begin{array}{l}\text { Jérôme Vergne, Hélène Pauchet, Mickaël Bonnin and } \\
\text { the RESIF-CLB Team }\end{array}$ \\
\hline EGU2019-10829 & $\begin{array}{l}\text { Initial Test Results for Trillium Slim Borehole 120, } \\
\text { A New Small-Diameter High-Performance Seis- } \\
\text { mometer }\end{array}$ & $\begin{array}{l}\text { Geoffrey Bainbridge, Peter Devanney, and } \\
\text { Bruce Townsend }\end{array}$ \\
\hline EGU2019-13102 & $\begin{array}{l}\text { Testing the readiness of strong motion sensors for } \\
\text { Earthquake Early Warning }\end{array}$ & $\begin{array}{l}\text { Frederick Massin, John Clinton, Roman Racine, and } \\
\text { Yara Rossi }\end{array}$ \\
\hline EGU2019-13330 & $\begin{array}{l}\text { Seismic monitoring of the Laa a. d. Thaya - } \\
\text { Pasohlávky border region of Austria and Czech } \\
\text { Republic }\end{array}$ & $\begin{array}{l}\text { Fee-Alexandra Rodler, Stefan Weginger, Maria- } \\
\text { Theresia Apoloner, Yan Jia, and Wolfgang Lenhardt }\end{array}$ \\
\hline EGU2019-13460 & Advances in active integrated sensor systems & Sally Mohr, Phil Hill, and Stuart Allardice \\
\hline EGU2019-14427 & $\begin{array}{l}\text { A Review of Seismic Monitoring in Romania: im- } \\
\text { proved earthquake detection network capabilities }\end{array}$ & $\begin{array}{l}\text { Cristian Neagoe, Liviu Marius Manea, Alexandru Mar- } \\
\text { mureanu, and Constantin Ionescu }\end{array}$ \\
\hline EGU2019-16607 & $\begin{array}{l}\text { A complete characterization of } 27 \text { OSOP Raspber- } \\
\text { ryshakes performed at EOST Seismic Instrumenta- } \\
\text { tion Facility }\end{array}$ & $\begin{array}{l}\text { Maxime Bès de Berc, Romain Pestourie, Hélène Jund, } \\
\text { and Céleste Broucke }\end{array}$ \\
\hline EGU2019-17905 & $\begin{array}{l}\text { Reliability quantification of the intensities predicted } \\
\text { by the Seismic Automatic Determination (DAS) } \\
\text { system of the Catalan seismic network }\end{array}$ & $\begin{array}{l}\text { Nuria Romeu, Josep Batlló, Tanit Frontera, } \\
\text { Janira Irizarry, Jose Antonio Jara, and Sara Figueras }\end{array}$ \\
\hline EGU2019-18334 & $\begin{array}{l}\text { A GIS model for seismic station sites selection. } \\
\text { Case of study Chiapas State, Mexico }\end{array}$ & $\begin{array}{l}\text { Antonio Noe Aguilar, Arturo Montalvo, } \\
\text { Luis Manuel García, and Juan Antonio Vargas }\end{array}$ \\
\hline EGU2019-18695 & $\begin{array}{l}\text { Long-term self-noise estimates of broadband } \\
\text { seismic sensors from a high-noise vault }\end{array}$ & Shawn Goessen and Stephen Hicks \\
\hline
\end{tabular}


Austria, Italy, Canada, Switzerland, United Kingdom, Romania, Spain, Mexico), in 3 continents (Asia, Europe, North America), which fits well to the goals of the European Geosciences Union.

The solicited presentations in this session were the following:

i. "New federated seismological services within EIDA", by Javier Quinteros, Daniel Armbruster, Massimo Fares, Stefan Heimers, Andres Heinloo, Mathias Hoffmann, Philippe Kaestli, Mathijs Koymans, Erich O. Muhire, Cristian Neagoe, Mehmet Ozer, Catherine Pequegnat, Jonathan Schaeffer, Luca Trani, and Nikolaos Triantafyllis (Quinteros et al., 2019);

ii. "Quality Improvement of the French Permanent Broadband Stations with Shallow Posthole Installations", by Jérôme Vergne, Hélène Pauchet, Mickaël Bonnin and the RESIF-CLB Team (Vergne et al., 2019).

\section{Conclusions}

The quality and quantity of presentations made at the EGU2019 SM5.2/GI4.13 session satisfied the expectations of the convener and co-conveners and fit the goals of the European Geosciences Union.

This year the number of presentations at the seismic networks session increased: therefore the conveners after so many years are still confident that the path they followed in organizing such sessions at the yearly EGU General Assembly is a valid one, since there is a clear benefit in the seismological community worldwide to present and discuss different solutions to common problems in running seismic networks.

Special issue statement. This article is part of the special issue "Improving seismic networks performances: from site selection to data integration (EGU2019 SM5.2 session)". It is a result of the EGU General Assembly 2019, Vienna, Austria, 7-12 April 2019.

Acknowledgements. The authors wish to thank the authors of the EGU2019 SM5.2/GI4.13 session presentations, especially those who made the effort to publish their presentations in these proceedings in Advances in Geosciences. The authors also especially thank the EGU Seismology Division President Paul Martin Mai, for his support of the seismic networks session at the EGU.

\section{References}

EGU2011: SM1.3/G3.8/GD3.7/GI-19/TS8.7 Improving seismic networks performances: from site selection to data integration, available at: http://meetingorganizer.copernicus.org/EGU2011/ session/7340 (last access: 6 May 2015), 2011.

EGU2015: SM1.2/GI1.5 Improving seismic networks performances: from site selection to data integration, available at: http://meetingorganizer.copernicus.org/EGU2015/session/17368 (last access: 20 December 2019), 2015.

EGU2016: SM7.3 Improving seismic networks performances: from site selection to data integration, available at: https:// meetingorganizer.copernicus.org/EGU2016/session/20390 (last access: 20 December 2019), 2016.

EGU2017: SM5.3 Improving seismic networks performances: from site selection to data integration, available at: https:// meetingorganizer.copernicus.org/EGU2017/session/23188 (last access: 20 December 2019), 2017.

EGU2018: SM5.01/NH4.16 Ground translation, strain and rotation: New and improved instrumentation and applications, available at: https://meetingorganizer.copernicus.org/EGU2018/ session/28286 (last access: 20 December 2019), 2018.

EGU2019: SM5.2/GI4.13 Improving seismic networks performances: from site selection to data integration, available at: https: //meetingorganizer.copernicus.org/EGU2019/session/31880 (last access: 20 December 2019), 2019.

Pesaresi, D.: The EGU2010 SM1.3 Seismic Centres Data Acquisition session: an introduction to Antelope, EarthWorm and SeisComP, and their use around the World, Ann. Geophys.-Italy, 54, 1-7, https://doi.org/10.4401/ag-4972, 2011.

Pesaresi, D. and Busby, R.: EGU2013 SM1.4/GI1.6 session: "Improving seismic networks performances: from site selection to data integration", Adv. Geosci., 36, 1-5, https://doi.org/10.5194/adgeo-36-1-2013, 2013.

Pesaresi, D. and Vernon, F.: EGU2012 SM1.3/GI1.7 session: "Improving seismic networks performances: from site selection to data integration", Adv. Geosci., 34, 1-4, https://doi.org/10.5194/adgeo-34-1-2013, 2013.

Pesaresi, D., Clinton, J., and Pedersen, H.: Preface: Improving seismic networks performances: from site selection to data integration (EGU2014 SM1.2/GI3.7 session), Adv. Geosci., 40, 19-25, https://doi.org/10.5194/adgeo-40-19-2015, 2015.

Quinteros, J., Armbruster, D., Fares, M., Heimers, S., Heinloo, A., Hoffmann, M., Kaestli, P., Koymans, M., Muhire, E. O., Neagoe, C., Ozer, M., Pequegnat, C., Schaeffer, J., Trani, L., and Triantafyllis, N.: New federated seismological services within EIDA, EGU General Assembly, 7-12 April 2019, Vienna, Austria, EGU2019-13810, 2019.

Vergne, J., Pauchet, H., Bonnin, M., and the RESIF-CLB Team: Quality Improvement of the French Permanent Broadband Stations with Shallow Posthole Installations, EGU General Assembly, 7-12 April 2019, Vienna, Austria, EGU2019-7691, 2019. 